原著

\title{
吸啜舌運動の中枢性リズム発生器の局在 新生仔ラット摘出脳幹-脊髄標本における解析
}

\author{
劉嘉 \\ 東京医科歯科大学歯学部口腔生理学講座（指導：中村嘉男教授）
}

(1997 年 9 月 29 日 受付)

\section{Localization of Central Rhythm Generator for Tongue Movements in Sucking - Analysis of Isolated Brainstem-spinal cord Preparation from Newborn Rats _}

\author{
Liu Jia
}

\begin{abstract}
Department of Physiology, Faculty of Dentistry, Tokyo Medical and Dental University (Director : Prof. Yoshio Nakamura)
\end{abstract}

Localization of the central rhythm generator (CRG) for tongue movements in sucking was studied in in vitro brainstem-spinal cord preparations from newborn rats, using the rhythmical sucking-like activity (RSA) of the hypoglossal nerve (XII) induced by perfusion of $N$-methylD-aspartate (NMDA) as the index of sucking. Sulforhodamine 101 (S 101), a fluorescent dye taken up by neurons in an activity dependent manner, was applied to the preparations which showed only spontaneous inspiratory activity in XII without NMDA application and to those which showed NMDA-induced RSA in XII. In both preparations, the neurons labelled with S 101 were found in the hypoglossal nucleus, facial nucleus, ambiguous nucleus, solitary tract nucleus, trigeminal spinal nucleus, inferior olivary nucleus, gigantocellular, lateral and ventral reticular nuclei. More neurons were labelled more intensely in the latter preparations. The difference was particularly conspicuous in the gigantocellular reticular nucleus, suggesting that it plays an especially important role in central rhythm generation of sucking. The NMDA-induced RSA in XII persisted after removal of the dorsal medulla oblongata, the caudal pons constituting a part of the CRG for mastication, and the trigeminal spinal nucleus relaying afferents in sucking reflex. It was concluded that the CRG for tongue movements in sucking is localized in the ventromedial medulla oblongata.

\section{I . 諸言}

吸啜および咀嚼運動は顎・舌・顔面の協調運動 によって遂行されるリズム運動であり，この点で 呼吸ならびに歩行などのリズム運動と共通の特徵 を有している。このリズム活動の運動司令は基本 的に中枢神経内で形成されており，この形成機構
は中枢性リズム発生器と呼ばれている。咀嚼運動 の中枢性リズム発生器については, 成熟モルモッ トにおける解析により，巨大細胞網様核を含む橋 尾側部ならびに延髄網様体内側部に局在すること が明らかにされている1 3)。

母乳の吸嗓から固形食物の咀嚼への転換は哺乳 動物の摂食行動の生後発達の基本的特徵である 
が，吸啜リズムについては，モルモット新生仔に おける解析によって, 咀嚼と同じく, 中枢神経系 に内在するリズム発生器により形成されること, ならびに，このリズム形成には咀嚼のリズム発生 器の局在する巨大細胞網様核を含む橋・延髄網様 体の内側部が必須の役割を演ずることが明らかに されている4)。しかし，咀嚼と吸啜とが同一の中枢 性リズム発生器によって形成されるのか，あるい は両者が別個のリズム発生器によって形成される のかについては全く不明である。

哺乳動物の遊離中枢神経標本は, 呼吸 ${ }^{5 \sim 10)}$ お び歩行運動, 911 13)のようなリズミカルな運動の中 枢性パタン形成機構の生理学的, 薬理学的研究の ために，きわめて価値の高い標本として用いられ てきた。そして，灌流液中への興奮性アミノ酸の

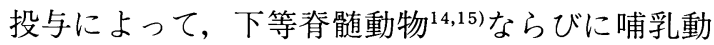
物の新生仔 ${ }^{9,12,13,16)}$ から遊離したin vitro 脊髄標 本の前根からリズミカルな活動が誘発されること が明らかにされている。また，後肢の筋を付けた まま遊離したラット新生仔の in vitro 標本で，灌 流液中への NMDA $(N$-methyl-D-aspartate $)$ 投 与によって，歩行運動様の筋電図活動が誘発され ている11)。これまでの研究で，NMDAならびに Kainate などの受容体の薬物による活性化によっ て歩行様神経活動が誘発され，NMDA 受容体は 特に有効であること年,15,17,18)や，quisuqualate 受 容体の活性化では誘発されないことが明らかにさ れている11,12,14,18,19)。

これに対して，哺乳動物の捸食行動に関連する リズミカルなロ腔・顔面運動の中枢ニューロン機 構の研究のための in vitro 標本は開発されていな かったが, Suzue(1984)の方法によって作成した ラット新生仔の in vitro 脳幹-脊髄標本において, 灌流液中への NMDA 投与によってリズミカルな 口腔・顔面運動に相当するリズミカルな群発運動

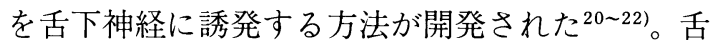
のリズミカルな運動は, 哺乳動物の新生仔で呼 吸・吸哆・嚥下に一致して認められるが, in vitro 脳幹-脊髄標本への NMDA 投与によって誘発さ れたリズミカルな舌下神経活動は, 種々の証拠か
ら吸啜運動中のリズミカルな活動に対応すると想 定される23)。

そこで, 本研究では, まず NMDA で誘発した舌 下神経の吸啜様リズム活動を吸啜リズム活動の指 標として，その発現に一致して活性化される ニューロンを標識することによって，吸啜運動の リズム発生に関与するニューロンの局在を明らか にすることを試みた。これらの活動ニューロンの 標識には，蛍光色素 Sulforhodamine 101 (S 101) が適していると思われた。その理由は，この色素 によって，興奮した運動神経終末の標識 ${ }^{24)}$, in vitro 脳幹-小脳標本の脊髄背外側束の電気刺激に より活動を示す赤核ニューロンの標識 25 に成功し た報告があるからである。

次いで, この標識ニューロンの脳幹内の分布に 基づいて, in vitro 脳幹-脊髄標本にさまざまな切 断を加之, 吸啜様活動の中枢性形成に関与するリ ズム発生器の局在を検索した。

\section{II. 方法}

\section{1. 標本の作製と記録}

実験には生後 0 ～3 日のィスター系ラット新

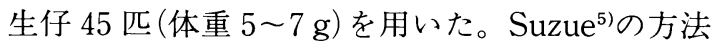
に従って, エーテル麻酔下で小脳を除去し, 吻側 は四丘体間のレベルで除脳した後，尾側は第 8 頸 髄のレベルで切断し，脳幹および脊髄を，三叉・ 顔面・舌下神経および頸髄前根ならびに後根とと もに摘出した。次いで，この摘出脳幹-脊髄標本を 記録槽中に腹側面を上にして固定し， $95 \% \mathrm{O}_{2}-5 \%$ $\mathrm{CO}_{2}$ 混合ガスで飽和した人工脳脊髄液 $(130 \mathrm{mM}$ ： $\mathrm{NaCl}, 3.0 \mathrm{mM}: \mathrm{KCl}, 1.25 \mathrm{mM}: \mathrm{KH}_{2} \mathrm{PO}_{4}, 3.0$ $\mathrm{mM}: \mathrm{CaCl}_{2}, \quad 1.3 \mathrm{mM}: \mathrm{MgSO}_{4}, 26 \mathrm{mM}$ : $\mathrm{NaHCO}_{3}, 28.8 \mathrm{mM}$ : glucose ; pH 7.5; $\left.25 \sim 27^{\circ} \mathrm{C}\right)$ で灌流した $(5 \mathrm{ml} / \mathrm{min})$ 。横隔神経に軸 索を送る第 4 あるいは第 5 頸髄前根および舌下神 経にガラス吸引電極を装着して，神経活動を記録 した(図 1)。ガラス吸引電極の先端内径は 50 130 $\mu \mathrm{m}$ で, 内部は灌流液と同一組成の人工脳脊髄液 で満たした。神経活動は 2 チャンネル前置増幅器 (日本光電：JH-220 J, 周波数帯域：0.08 10 


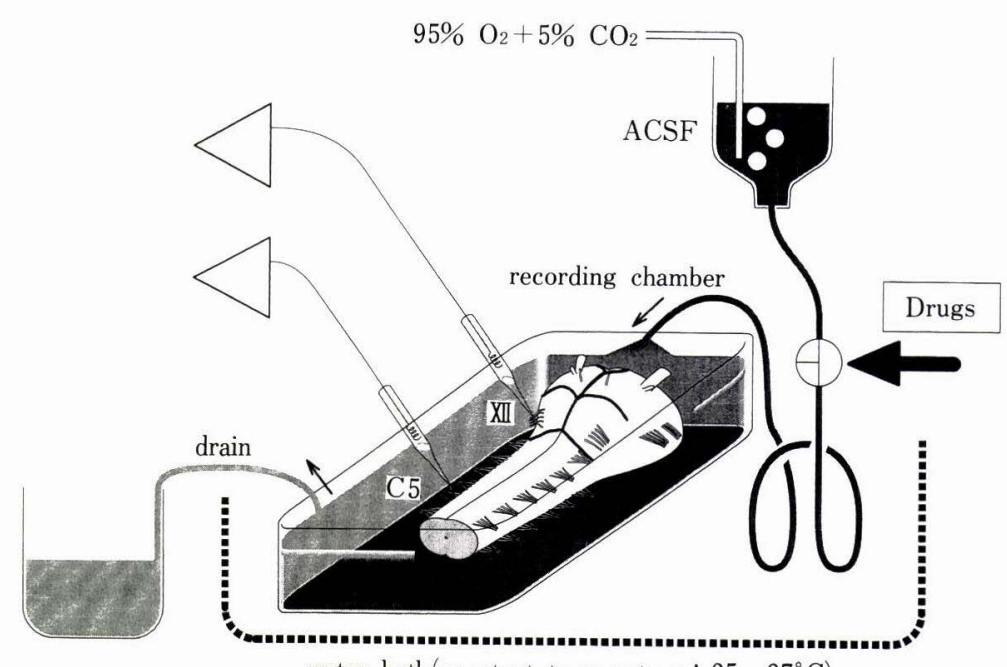

water bath (constant temperature : $25 \sim 27^{\circ} \mathrm{C}$ )

図 1 実験系の構成

標本を設置する記録槽は $95 \% \mathrm{O}_{2}-5 \% \mathrm{CO}_{2}$ 混合がスで飽和した $\mathrm{pH} 7.5$ の人工脳脊髄液で灌流する。灌流液は重力により記録槽内に導 き, 水流ポンプによって吸引することで灌流を行い, 記録槽内の温度計 によって液温をモニターし，ヒーターによって液温を $25 \sim 27^{\circ} \mathrm{C} に$ 維持 する。記録は舌下神経および第 4 あるいは第 5 頸骾前根にガラス吸引 電極を装着して行う。NMDA は三方活栓を用いて灌流液中に加える。

$\mathrm{kHz}$ ) と生体電気用増幅器 (日本光電： $\mathrm{AB}-651 \mathrm{~J}$, 周波数帯域：0.08〜 $10 \mathrm{kHz}$ ) で増幅し，オシロス コープ (Kenwood：CS-8010) とサーマルレコー ダ(NEC：8 M 36)でモニターした。また JH-220 $\mathrm{J}$ の出力はデータレコーダ (TEAC：RD-135 T, 周波数带域：DC 3 kHz) に入力し，実験終了後 に，記録を再生してデー夕処理を行った。

\section{NMDA の投与}

NMDA 投与前, 舌下神経および第 4 あるいは 第 5 頸髄前根に, 自発性の呼吸リズム活動が出現 していることを確認した後, 灌流液中に NMDA $(15 \sim 20 \mu \mathrm{M})$ を 5 分間投与して，舌下神経に自発 性呼吸活動と異なるリズミカルな神経活動を誘発 し，この活動を持続するためにNMDA（4～8 $\mu \mathrm{M})$ を持続的に投与した。

\section{Sulforhodamine の投与}

45 匹中の 10 匹のラット新生仔から摘出した脳 幹-脊髄標本を用いた。対照として 5 匹でNMDA を投与せず自発性呼吸活動のみが観察される条件
で, $0.001 \sim 0.0025 \%$ Sulforhodamine 101 (S 101) を含む人工脳脊髄液で 60 ～ 141 分間灌流した。ほ かの 5 匹では NMDAの投与によって誘発したリ ズミカルな活動が出現した後, NMDA $(4 \sim 8 \mu \mathrm{M})$ および $0.001 〜 0.0025 \%$ S 101 を含む人工脳春髄 液で 35〜168 分間灌流した。いずれの標本も，実 験終了後, 4\%Paraformaldehyde phosphate buffer ( $\mathrm{pH} 7.4$ ) を用いて固定し, 厚さ $40 \sim 60 \mu \mathrm{m}$ の前頭断の連続凍結切片を作成し, 蛍光顕微鏡下 でS 101 で標識されたニューロンおよび線維の局 在部位を組織学的に検索した。

\section{4. 脳幹の切断}

45 匹中の 35 匹のラット新生仔から摘出した脳 幹一脊髄標本を用いて, 切断実験を行った。NMDA 投与によって舌下神経に吸哆様りズム活動が誘発 されたのを確認した後, 両刃の剃刀の刃から作成 した切断刀を用いて，標本に前頭面，水平面ある いは矢状面方向の切断を加えた。切断後, NMDA (15〜20 $\mu \mathrm{M})$ を再び投与し, 舌下神経から, 吸哆 
様のリズミカルな活動が誘発されるか否かを検討 した。実験終了後，標本を 4\%Paraformaldehyde phosphate buffer (pH 7.4) で固定し，厚さ 40 60 $\mu \mathrm{m}$ の前頭断あるいは水平断の凍結連続切片を作 成し， cresyl violet で染色し，切断後に残存する 領域を組織学的に検索した。

\section{III. 結 果}

1. NMDA 投与により発現する舌下神経のリズム 活動出現に一致して活動するニューロンの局在

10 匹のラット新生仔から遊離したin vitro 脳 幹-脊髄標本で NMDA 投与前には自発性のリズ ミカルな群発活動が，横隔神経に軸索を送る第 4 あるいは第 5 頸䯣前根ならびに舌下神経に出現し た。図 $2 \mathrm{~A}$ はその 1 例を示す。この群発活動は周 期が $12 \sim 15 \mathrm{~s}$ で，舌下神経と頸髄前根に同期して 出現し, 持続時間 $0.8 \sim 1.5 \mathrm{~s}$, 振幅は $100 \sim 400 \mu \mathrm{V}$ で，急速な上昇相およびこれより緩徐な下降相か ら構成されていた。

この 10 例中， 5 例で NMDA $(5 \sim 20 \mu \mathrm{M})$ の投 与により，舌下神経に頸髄前根の吸息活動と同期 した活動に加えて，このリズム活動とは別のリズ ミカルな群発活動が出現した（図 $2 \mathrm{~B}$ 上段）。 NMDA で誘発されたこの群発活動の周期は $2.5 \sim 3.0 \mathrm{~s}$ で吸息活動の周期より著しく短く，持

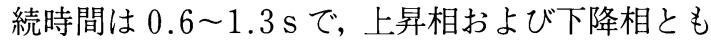
に吸息活動より緩徐であり，振幅は $40 \sim 170 \mu \mathrm{V}$ で，明らかに小さかった(図 2 B)。この群発活動 は，吸息活動とは周期，振幅，波形によって容易 に区別された。

図 3 は，NMDA 投与によって舌下神経にリズ ム活動が出現した 5 例中の 1 例で，S 101 によっ て標識されたニューロンの分布を示す舌下神経中 央付近の前頭断切片の顕微鏡写真である。図 $3 \mathrm{~A}$ で白く見える点が S 101 で標識された細胞であ る。図 $3 \mathrm{~B}$ は Aの白枠で囲まれた領域の強拡大の 顕微鏡写真であり，舌下神経核の部位に相当して いる。標識された舌下神経運動ニューロンの細胞 体中に S 101 が球状に集積している像が観察され た。一方，下オリーブ核のニューロンのような小
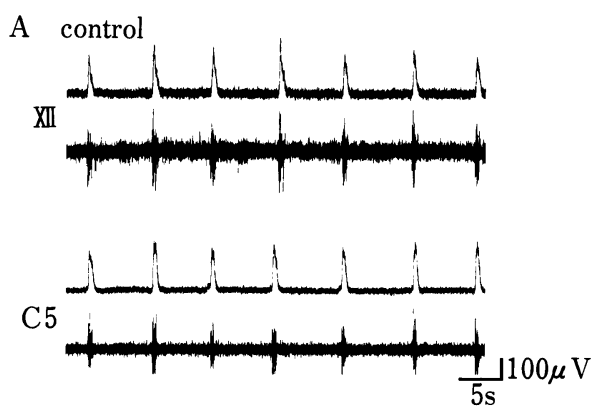

B NMDA $6 \mu \mathrm{M}$

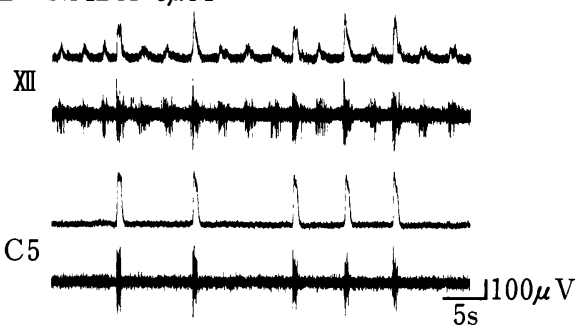

図 2 NMDAの投与によって舌下神経に誘 発されるリズミカルな神経活動

A：NMDA 投与前の記録。B：灌流液 中に NMDA $(6 \mu \mathrm{M})$ を投与した際の記 録。上下 2 対の記録は，それぞれ舌下神 経（XII） と第 5 頸䯣前根（C 5) のリズ ミカルな群発活動を示し，それぞれの下 段は群発活動の原波形，上段はその積分 波形を表す。A では自発性の吸息活動が XII とC5に見られる。BではXIIに吸 息活動とともにそれとは明らかに異なっ たリズミカルな群発活動が出現してい る。

型細胞がS 101 によって数多く標識された部位 や，標識された線維は弱拡大の顕微鏡写真では領 域全体が濔漫性に蛍光を示した。

図 $4 \mathrm{~A}$ は対照として，NMDAを投与せず自発 性吸息活動のみが観察された条件でS 101 の 120 分投与によって標識された脳幹ニューロンの分布 の 1 例を示したものである。舌下神経核 $(\mathrm{XIIN})$, 顔面神経核 (VIIN)，疑核 (AM)，巨大細胞網様 核 (GC) 尾側部，孤束核 (Sol)，三叉神経脊髄路 核 $(\mathrm{SpV})$ ，下オリーブ核 $(\mathrm{IO})$ などに標識された 細胞体が認められた。

図 $4 \mathrm{~B}$ は NMDA 投与によってリズミカルな舌 

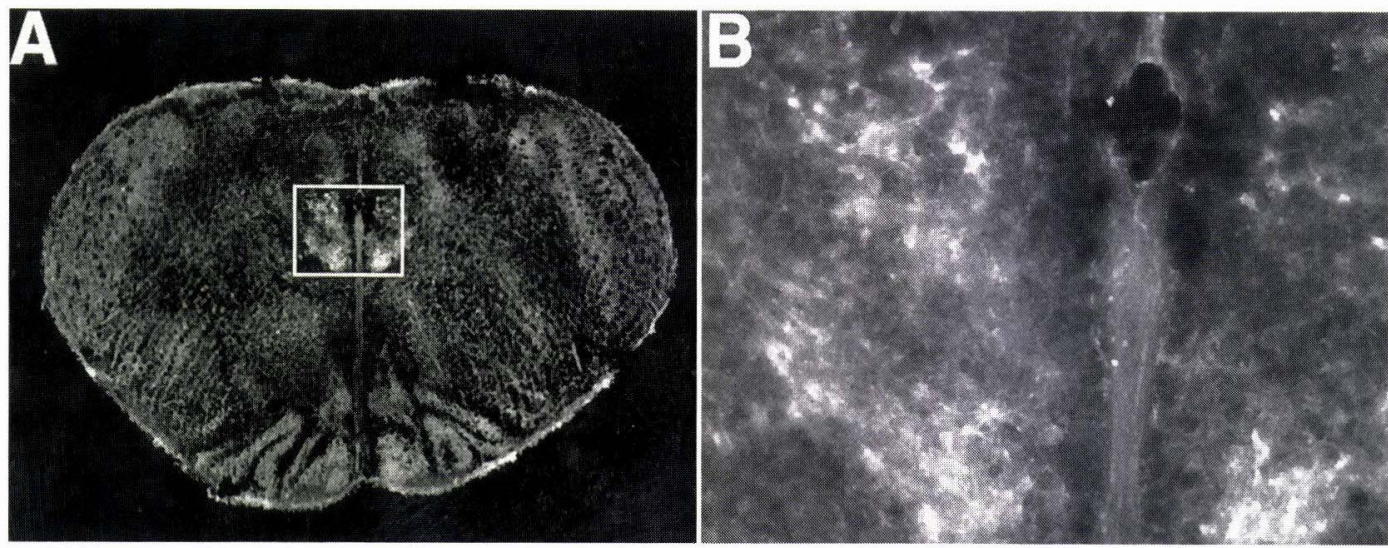

図 3 NMDA で誘発された舌下神経のリズム活動出現に一致して S 101 によって標識された脳幹二ュ一 ロンの局在部位を示す前頭断標本の顕微鏡写真

$\mathrm{A}$ ：舌下神経核中央レベルに扔ける前頭断切片。白く見える点が S 101 で標識された細胞。B：Aの なかの白枠で囲まれた舌下神経核の領域の強拡大写真

下神経活動を示した群で S 101 によって標識され た脳幹ニューロンの分布の 1 例を示している。 NMDA 持続投与で誘発したリズミカルな舌下神 経活動出現中に S 101 を 140 分投与したこの例で は, 図 $4 \mathrm{~A}$ に比べて, 舌下神経核, 巨大細胞網様 核, 孤束核, 三叉神経脊髄路核などで, 標識二ュー ロン数の増加と蛍光の強度の上昇が観察された。

表 1 は対照群と NMDA 投与群との S 101 で標 識された細胞の分布を一覧表として示したもので ある。標識されたニューロンは舌下神経核, 顔面 神経核, 疑核, 孤束核, 三文神経脊髄路核, 下才 リーブ核, 外側網様核, 巨大細胞網様核, 延髓腹 側網様核，頸䯣後角などに見いだされた。薄い㓌 影は中等度蛍光を示す部位を示しており，顔面神 経核, 孤束核, 外側網様核に一致し，小型二ュ一 ロンや線維も標識されていた。濃い㓌影は小型 ニューロンや線維が数多く標識されたため, さら に強い蛍光を示した部位を示し, 舌下神経核, 三 叉神経脊髄路核，下オリーブ核，頸髄後角などに 分布していた。

以上の結果から，NMDA 投与による吸啜様り ズム活動の出現に対応して活動の上昇している ニューロンの存在する部位が明らかになったの で, 次に脳幹一脊髄標本に種々の切断を加えて,
NMDA による舌下神経のリズム活動の誘発に必 須な部位を検索した。

\section{2. 脳幹の切断}

1) 前頭面切断

図 5 は脳幹-冾䯣標本に舌下神経根の最吻側レ ベルならびに延髄一春髄境界部で前頭断（図 $5 \mathrm{~A}$ ) を加えた結果の 1 例を示す。切断後も, NMDA (6 $\mu \mathrm{M})$ の投与により舌下神経に吸哆様リズム活動 が出現し，吸息活動も残存した(図 5 B)。図 5 Cの 水平断標本で見られるように，この例では切断に より顔面神経核の尾側部より吻側が除去されてい るが,下オリーブ核の吻側端レベルより尾側は残 存していた。これと同一レベルの切断を行ったほ かの 8 例の標本においても, 自発性吸息活動およ びNMDA 投与によるリズム活動の両者とも残存 した。しかし，これより尾側のレベルで前頭断を 加えた標本 4 例では, NMDA $(6 \mu \mathrm{M})$ を投与して も, 舌下神経に吸啜様リズム活動ならびに吸息活 動は出現した例はなかった。これらの例では, 組 織学的な検索の結果, 顔面神経核とともに, 下才 リーブ核および舌下神経核の一部も除去されてい ることが明らかにされた。

2) 水平面切断

図 6 は延髄-春髄標本に水平切断（図 $6 \mathrm{~A}$ ) を加 
A

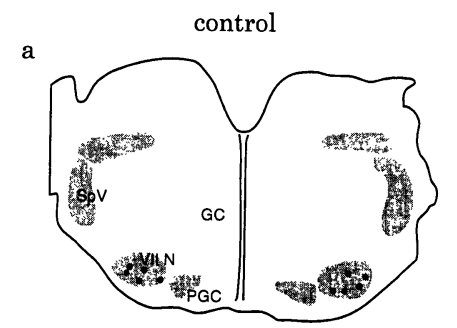

b

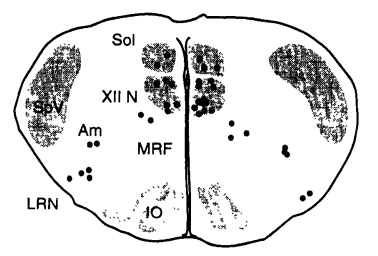

c

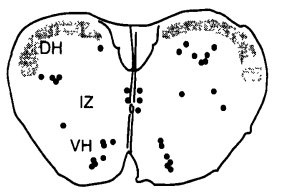

B

a

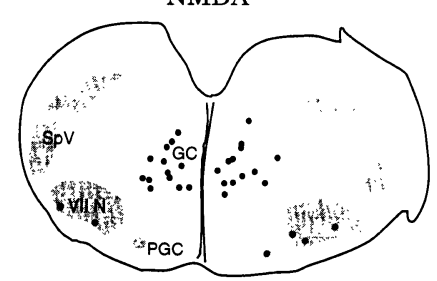

b

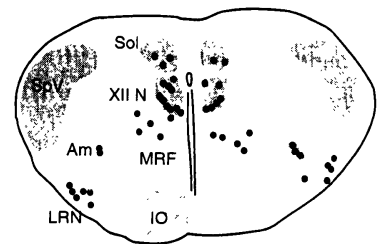

c

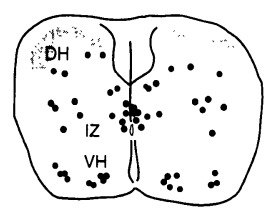

図 4 S 101 で標識されたニューロンの分布を示す脳幹前頭断面の模式困 A : NMDA を投与せず自発吸息活動のみが観察される条件で S 101 によって標識された脳幹ニューロンの分布。B：NMDA 投与群で S 101 によって標識された脳幹二ューロンの分布。a，b，cは，それぞ れ顔面神経核, 舌下神経核中央部, C 2 (A) あるいは C 4 (B) レベル に相当する。黒丸は強く標識された細胞体の存在部位で, 除影を付けた 部位は, 標識されてはいるが, 個々の細胞体を明瞭に区別できない領域 を示す。

[略語] Am：疑核, DH：後角, GC：巨大細胞網様核, IO：下才リ一 ブ核, IZ：中間層, LRN : 外側網様核, MRF : 延髄腹側網様核, PGC : 傍巨大細胞網様核, $\mathrm{Sol}$ : 孤束核, $\mathrm{SpV}$ : 三叉神経脊骾路核, $\mathrm{VH}$ : 前角, VIIN：顔面神経核, XIIN：舌下神経核

え，背側を除いた結果の 1 例を示す。薄束結節と 楔状束結節を含む延髄背側部を除去した後も， $\operatorname{NMDA}(6 \mu \mathrm{M})$ の投与により, 舌下神経に吸啜様 リズム活動と吸息活動が観察された（図 6 B)。組 織学的検索の結果, 孤束核が除去されていること が明らかになった（図 6 C)。図 $6 \mathrm{~A}$ と同様な水平 切断を全部で 10 匹から得られた延髄一脊髄標本で 行ったが，切断後も全例でNMDAによる吸啜様 リズム活動は残存した。これに対して，これより 腹側のレベルで水平切断を加えた 5 例では, いず れの標本でも, 切断後は NMDA $(6 \mu \mathrm{M})$ を投与
しても舌下神経の吸啜様リズム活動も吸息活動も 観察されなかった。組織学的な検索の結果, これ らの例では孤束核とともに舌下神経核の一部も除 去されていることが見いだされた。

3）矢状面切断

図 7 は延髄-春䯣標本の外側部に矢状方向の切 断 (図 $7 \mathrm{~A}$ ) を加之た結果の 1 例を示す。切断は舌 下神経根が延髄から出る部位の外側に直接隣接す る部位で両側性に加えた。切断後, $\operatorname{NMDA}(6 \mu \mathrm{M})$ を投与によって舌下神経に誘発されていた吸嗓様 リズム活動および吸息活動の両者とも残存した 
表 1 in vitro 脳幹-脊䯣標本で S 101 によって標識された領域

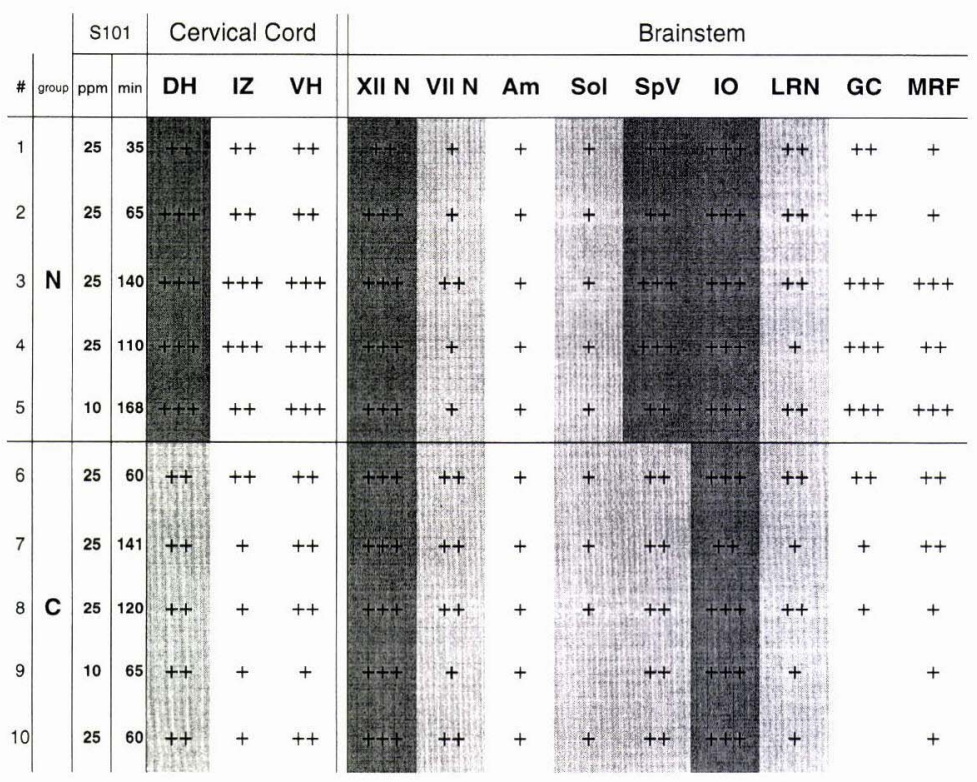

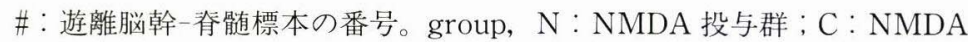
非投与群。 S 101 の濃度は $\mathrm{ppm}$, 投与時間を min で表す。切片当たり強く標

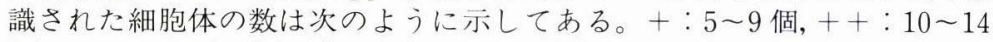
個, $+++： 15$ 個以上。薄い陰影を付けた部位は中等度に標識された領域, 濃い院影は強く標識された領域を示す。

[略語] DH：後角, IZ：中間層, VH：前角, XIIN：舌下神経核, VIIN： 顔面神経核, $\mathrm{Am}$ ：疑核, $\mathrm{Sol}$ : 孤束核, $\mathrm{SpV}$ : 三㕚神経脊随路核, IO : 下才 リーブ核, LRN : 外側網様核, GC : 巨大細胞網様核, MRF : 延髄腹側網様 核

(図 7 B)。この例では矢状方向の切断によって三 叉神経脊髄路核は両側とも除去されていた（図 7 C)。これと同一の矢状方向の切断を加えた全部で 7 例の標本のいずれにおいても, NMDA 投与によ る舌下神経のリズム活動は残存した。これより内 側での切断は，舌下神経も切断してしまうため本 研究では行わなかった。

\section{IV. 考 察}

\section{1） NMDA で誘発される舌下神経のリズム活動の}

\section{関与するロ腔機能}

舌のリズミカルな活動は, 哺乳動物では呼吸・ 咀嚼・吸啜・嚥下などに一致して認められる ${ }^{5,26)}$ それでは NMDAによってin vitro脳幹-春骾標
本で誘発された舌下神経のリズミカルな群発活動 は，これらの機能のどれに対応する活動なのであ ろうか? 種々の証拠から in vitro 脳幹-脊髄標 本への NMDA 投与によって誘発されたリズミカ ルな舌下神経活動は, 吸啜運動中のリズミカルな 舌運動に対応すると想定される ${ }^{23)}$ 。まず, NMDA 投与によって誘発されたこのリズミカルな舌下神 経活動は, 周期も群発の振幅, 時間経過のどちら も, 吸気運動に対応する群発活動とは全く相違し ている。次に, NMDA 投与によって誘発される舌 下神経活動は, 第 4 あるいは第 5 頸髄前根から記 録される吸気運動に対応する群発活動とは同期し ない。また, ラットの咀嚼行動は, 生後 12 日頃㐘 の萌出と一致して出現する ${ }^{26)}$ さらに, 舌運動のパ 
A

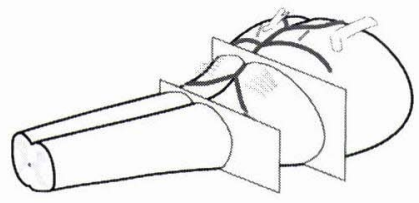

B

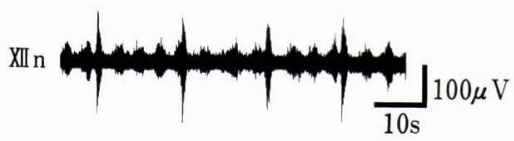

C
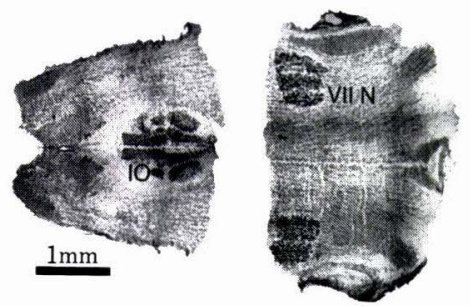

困 5 橋ならびに春䯣を除去するための前頭 切断

$\mathrm{A}$ ：切断の模式図。B：切断後, 舌下神 経のリズミカルな活動。高振幅の群発活 動は自発性の吸息リズム活動。C : 水平 断標本の顕微鏡写真。右は切断により除 去された吻側部分, 左は切断後の残存部 分。顔面神経核の尾側端より吻側の部位 が除去され，下オリーブ核の吻側端より 尾側の部位が残っている。

[略語] IO：下オリーブ核, VIIN：顔 面神経核

タンには，吸気運動と吸啜運動との間で対照的な 相違が見られる。すなわち，吸気運動では，下顎 の大きな下制とともに舌尖は大きく下方に移動 し, 舌体部は正中部が陥凹して気道を拡張するパ タンが見られるが，母乳の吸啜運動では，下顎の 下制は軽度で舌尖がリズミカルに挙上し舌体が下 制するパタンを示す。口腔・顔面組織を付けたま ま作成した遊離脳幹-春髄標本では, NMDA 投与 によって誘発されるリズミカルな舌運動は舌尖が リズミカルに挙上し舌体が下行するパタンを示 し，ラット新生仔の自然の母乳吸啜行動における 舌運動のパタンと実質的に同一である ${ }^{22)}$ 。また, 自 然の状態では, 吸啜行動に伴って嚥下が起こるが,
A

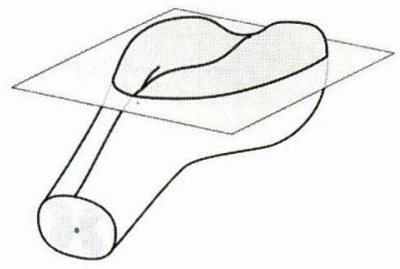

B

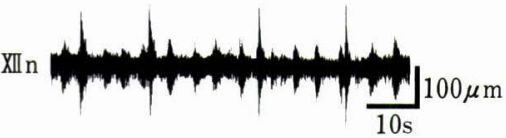

C

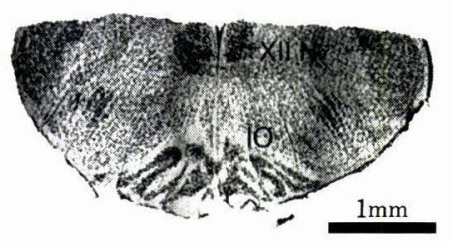

図 6 延髄背側部を除去するための水平切断 A：切断の模式図。B：切断後 NMDA の投与によって舌下神経のリズミカルな 活動。高振幅の群発活動は自発性の吸息 リズム活動。C：切断部位を示す前頭断 組織切片の顕微鏡写真。孤束核を含好 延骨直背側部が除去されている。

[略語] IO：下オリーブ核, XIIN：舌 下神経核

ラットの in vitro 標本でグルタミン酸やその作動 薬の孤束核への微量注入によって嚥下を誘発する ことができることが報告されている27)。したがっ て，NMDA を灌流液中に加えることによって in vitro 脳幹-脊髄標本に誘発されるリズミカルな舌 下神経活動は, NMDA が孤束核ニューロンに作 用して誘発された嚥下運動の出現に対応する神経 活動の可能性がある。しかし, 嚥下運動は三叉・ 顔面・舌咽・舌下神経などの脳神経のみならず, 上部頸髄前根を経由する脊髄神経によって支配さ れる多数の異なった筋群の協調運動である ${ }^{28)}$ 。し たがって, NMDA で誘発される舌下神経のリズ ミカルな活動が嚥下運動に関連する神経活動であ 
A

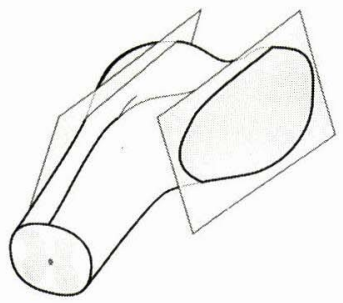

B

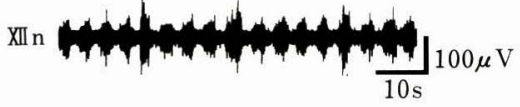

C

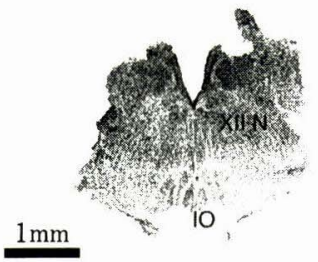

図 7 延䯣外側部を両側性に除去するための 矢状面方向の切断

A：切断の模式図。B：切断後 NMDA の投与によって出現した舌下神経のリズ ミカルな活動。高振幅の群発活動は自発 性の吸息リズム活動。C：切断部位を示 卞前頭断組織切片の顕微鏡写真。三叉神 経脊髄路核が両側性に除去されている。

[略語] IO：下オリーブ核, XIIN：舌 下神経核

れば，上部頸髄前根にも群発活動が出現するはず である。しかし, in vitro 脳幹-脊髄標本ではリズ ミカルな舌下神経活動に伴って上部頸髄前根にこ の上うな群発活動は出現しなかった。このような ことから，NMDAを灌流液中に加えることに よってin vitro 脳幹-春髄標本に誘発されるリズ ミカルな舌下神経活動は, 吸啜運動時の舌運動に 関与する活動と考えるのが最も妥当である。

\section{Sulforhodamine 101 によるニューロンの標識}

Sulforhodamine 101 (S 101) は，スルフォン酸 基を持つ小分子量の蛍光物質であり，エンドサイ トーシスによってニューロンに取り込まれると考 えられている ${ }^{25)}$ 。

S 101 は，興奮した運動神経終末から選択的に 取り込まれること ${ }^{24)}$, 視覚皮質のてんかん様活動
を示す部位の神経線維終末に選択的に取り込まれ る ${ }^{29)}$ こや, in vitro 脳幹一小脳標本の春髄刺激に より活動を示す赤核ニューロンに取り込まれるこ とが報告されている。神経-筋伝達が活性化される と, 運動神経線維終末にかけるシナプス小胞の代 謝回転が著しく促進される30)ので，S 101 は活動 性依存性にニューロンへ取り込まれると考えられ る。しかも，二ューロンの単発あるいは少数のス パイク発射では取り込みは起こらず，取り込みに はニューロンの群発発射のような強い興奮が必要 であることが, カメの in vitro 脳幹-小脳標本の赤 核二ューロンで示されている25)。したがって, 本研 究でS 101 によって標識されたニューロンは, リ ズミカルな群発活動などの興奮を起こしたニュー ロンであることが示唆される。

Keifer ら (1992)によれば，S 101 は赤核ニュー ロンの軸索終末に認められる場合もあるが，ほと んどの標識は細胞体および樹状突起に存在してい る。しかも，S 101 は細胞質に均一的に分布してい るのではなく, 膜で包まれた構造に特徵的な小胞 状の像を示す ${ }^{25)}$ 。本研究においても, S 101 は細胞 体に大量に認められ, しかも円形の小胞状の構造 として認められた。

細胞体の S 101 は，シナプス前軸索終末におい て取り込まれた S 101 が逆行性軸索輸送によって 細胞体へ運ばれたと考えることもできるが，細胞 体あるいは樹状突起から直接取り込まれた可能性 も否定できない。実際に，小脳プルキンエ細胞で は，標識物質が樹状突起で取り込まれ，30９９分 で細胞体に到達することが示されている31)。

本研究において S 101 によって細胞体が標識さ れたニューロンは，顔面神経，舌下神経などの脳 神経運動二ューロンのように，切断された軸索断 端が開放されたままで灌流液中のS 101 と接し て, 断端から S 101 が拡散によって軸索内へ流入 し，それが軸索輸送によって細胞体まで軍ばれた 可能性が除外できない。しかし，これらの脳神経 運動ニューロンの細胞体のS 101 も小胞状の像を 呈することを考えると，この標識物質が細胞体あ るいは樹状突起から取り込まれた可能性も除外で 
きないであろう。

これらの脳神経以外の S 101 で細胞体が標識さ れた脳幹ニューロンは，いずれも軸索を脳幹内に 終止するので, S 101 は軸索終末からの取り込み と細胞体あるいは樹状突起からの取り込みの可能 性と, どちらの可能性も考えられる。本研究では, S 101 で爾漫性に蛍光を呈し, 個々の微細構造を 識別できない領域が認められたが，このなかには S 101 を取り込んだ脳幹ニューロンの軸索終末が 含まれているかもしれない。

NMDAによるリズミカルな舌下神経活動出現 中に，灌流液中に加えた S 101 によって標識され る脳幹ニューロンのなかには, 呼吸活動をはじめ として舌下神経の吸啜様リズム活動とは直接関係 のない活動と関連して活性化されたニューロンが 存在するであろう。NMDA 非投与群と NMDA 投与によりリズミカルな吸哆様活動が出現した群 とで, S 101 による標識の結果を比較すると, 後者 のほうが標識細胞の数も多く，また濔漫性の蛍光 を示す領域の蛍光の強度も高いことは, 吸啜様活 動の出現に対応して活性化されたニューロンの数 の増加ならびに活動上昇と関連させて, 一般的に 理解することができよう。しかし巨大細胞網様核 では, NMDA 非投与群 5 例中 2 例でS 101 で標 識されたニューロンは全く認められず，残りの3 例でも標識されたニューロンはわずかであったの に対して，NMDA 投与による吸哆様りズム活動 を示した 5 例の全例で標識ニューロンが見いださ れ，しかもその数も NMDA 非投与群に比して著 しく多いことは，この核が吸啜様りズム活動の中 枢性形成に特に重要な役割を果たしている可能性 を示唆している。

\section{3. 脳幹切断による吸啜様リズム活動の中枢性パ タン発生器の局在部位の検索}

成熟モルモットでは，咀嚼運動の中枢性リズム 発生器は巨大細胞網様核を含む橋の尾側部から吻 側延髄内側部に局在することが明らかにされてい

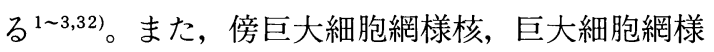
核などの延髄網様体内側部は，モルモット新生仔 で大脳皮質刺激によるリズミカルな吸哆様顎・顔
面運動の誘発に必須の役割を果たしていることが 報告されている4)。さらに，本研究における S 101 の投与により，NMDAによる舌下神経の吸啜様 リズム活動出現に一致して, 巨大細胞網様核 ニューロンが強く標識された。これらの結果は, 巨大細胞網様核が吸啜様リズム活動の発現に重要 な役割を果たしていることを示唆している。しか し, 本研究において, 成熟モルモットで咀嚼のリ ズム発生器の局在部位の吻側部である顔面神経レ ベルの橋尾側部を前頭断によって除去しても， NMDAによる吸啜様りズム活動の誘発は影響を 受けなかった。このことは, 新生仔ラットの吸啜 リズム発生器は, 成熟モルモットの咀嚼リズム発 生器とは局在を異にしていることを意味してい る。もし成熟ラットの咀嚼リズム発生器が成熟モ ルモットと同じく橋尾側部と延髄吻側部に局在す ると仮定すれば, 生後発達の過程で吸啜から咀嚼 への転換に一致して，捸食運動の中枢性パタン形 成機構に再構成が起こるという興味深い可能性が 示唆される。晚熟動物であるラットに対して，モ ルモットは早熟動物であり, 出生時にすでに永久 歯列を有し，固形食物の咀嚼が可能であることを 考えると，モルモット新生仔では，ラットの生後 のこの再構成が出生前にすでに完了しているのか もしれない。

孤束核には嚥下や呼吸に関係するニューロンが 存在している33)。また成熟ラットにおける孤束核 へのグルタミン酸局所投与により, 嚥下が誘発さ れることから，孤束核を中心とする延髄背側領域 に嚥下の中枢性パタン発生器が存在することが想

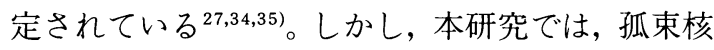
を含む延髄背側領域を切断によって除去した後で も，NMDAによって舌下神経に吸啜様リズム活 動が誘発された。このことは, 新生仔の吸啜様り ズムの中枢性形成機構は成熟動物の嚥下の中枢性 パタン形成機構とは独立の別のニューロン集団に よって構成されていることを意味している。この ことは, 本研究で, 孤束核におけるS 101 による ニューロンの標識の結果が, NMDA 非投与群で も NMDA 投与によって吸啜様リズム活動が出現 
している群と同様であった結果からも支持され る。

三叉神経脊髄路核にはグルタミン酸受容体が豊 富に存在していることが報告されている36 38)。本 研究における S 101 投与によって，NMDAによ る舌下神経の吸啜様リズム活動の出現に一致し て，三叉神経脊髄路核の標識の強度が明らかに上 昇した。このことは，S 101 投与による舌下神経の 吸啜様リズム活動の誘発に, 三叉神経脊髄路核が 関与する可能性を示唆しているが，遊離脳幹に矢 状断を加之て, 三叉神経脊髄路核を含む延䯣外側 部を両側性に除去しても，NMDA 投与による舌 下神経の吸啜様りズム活動の誘発効果は残存し た。したがって，三叉神経脊髄路核は舌下神経の 吸啜様りズム活動の中枢性形成に必須の役割を果 たしてはいない。

以上のことから，ラットの舌下神経の吸啜活動 の中枢性リズム発生に必須の構造は，巨大細胞網 様核，腹側網様核などを含む延髄腹内側領域に局 在すると結論される。

\section{V. 要 約}

ラット新生仔 in vitro 脳幹-脊髄標本を用いて, NMDAの灌流液中への投与によって誘発される 舌下神経の吸哆様りズム活動を指標にして，吸啜 運動のリズムを発現させる中枢運動司令の形成に 必須のニューロン集団あるいは回路（中枢性リズ ム発生器）の局在を検察した。

活動依存性にニューロンに取り込まれる蛍光色 素 Sulforhodamine 101（S 101）を, NMDA 投与に よって吸啜様りズム活動が舌下神経に出現中に投 与し，これによって標識されるニューロンの局在 および数を，NMDA を投与せず自発性のリズミ カルな吸気活動だけが出現している標本において 標識されるニューロンの局在および数と比較し た。どちらの場合にも, 舌下神経核, 顔面神経核, 疑核, 孤束核, 三叉神経脊髄路核, 下オリーブ 核, 外側網様核, 巨大細胞網様核, 腹側網様核 などに認められた。これらの標識結果を, NMDA 投与群と非投与群とで比較すると, 投与群のほう
が非投与群より，標識されたニューロンの数が多 く，また蛍光も強かった。これは，吸啜様りズム 活動の出現に一致して活性化されたニューロンの 数ならびに活動の増加を反映するものと想定され る。これらの核のなかで，巨大細胞網様核では， NMDA 非投与群では標識されたニューロンの認 められなかった例が 5 例中 2 例認められたのに対 して, 投与群では 5 例全例で標識ニューロンが見 いだされ，またその数も非投与群で標識ニューロ ンが認められた例に比して著しく多かった。この 結果は, この核が吸啜運動の中枢性リズム形成で 特に重要な役割を果たしていることを示唆してい る。

NMDA 投与による舌下神経の吸啜様リズム活 動は, 成熟動物の咀嚼りズム形成に必須の役割を 果たす領域の一部を構成する顔面神経核レベルの 橋尾側部，孤束核を含む延髄背側部，吸啜反射で 感覚性入力の伝達に関与する三叉神経脊髄路核 を，脳幹に切断を加えて除去しても残存した。

以上の結果から, 吸啜舌運動の中枢性りズム発 生器は, 巨大細胞網様核, 腹側網様核を含む延䯣 腹内側部に局在すると結論される。

\section{謝 辞}

稿を終わるにあたり，終始ご兓篤なるご指導とご校 閲を賜った東京医科歯科大学歯学部口腔生理学講座 中村嘉男教授に謹んで謝意を表します。また終始，懇 切なるご教示, ご校閲くださった口腔生理学講座助手 片倉伸郎先生に心より感謝いたします。さらに, 本研 究に際し,ご協力いただきました口腔生理学講座の諸 先生方に厚く御礼申し上げます。

本研究の一部は, 第 75 回 IADR 学会学術大会, 第 60 回ならびに第 61 回口腔病学会学術大会にて発表し た。

\section{文献}

1) Nozaki, S., Iriki, A. and Nakamura, Y. : Localization of central rhythm generator involved in cortically induced rhythmical masticatory jaw ${ }^{-}$ opening movement in the guinea pig. J. Neurophysiol. $55: 806-825,1986$.

2) Nozaki, S., Iriki, A. and Nakamura, Y. : Role 
of corticobulbar projection neurons in cortically induced rhythmical masticatory jaw-opening movement in the guinea pig. J. Neurophysiol. 55:826-845, 1986.

3）野崎修一：咀嚼リズム発見に関与する神経機構. 口病誌 $60: 327-343,1993$.

4) Iriki, A., Nozaki, S. and Nakamura, Y. : Feeding behavior in mammals; corticobulbar projection is reorganized during conversion from sucking to chewing. Brain Res. 44:189-196, 1988.

5) Suzue,T. : Respiratory rhythm generation in the in vitro brain stem-spinal cord preparation of the neonatal rat. J. Physiol. 354 : 173-183, 1984.

6) Walton, K. and Llinas, R. : An isolated in vitro preparation of the neonatal rat brain stem and spinal cord. Soc. Neurosci. Abstr. 11:24, 1985.

7) Harada, Y., Kuno, M. and Wang, Y. Z. : Differential effects of carbon dioxide and $\mathrm{pH}$ on central chemoreceptors in the rat in vitro. J. Physiol. 368 : 679-687, 1986.

8) Onimaru, H. and Homma, I. : Respiratory rhythm generator neurons in medulla of brainstem -spinal cord preparation from newborn rat. Brain Res. 403：380-384, 1987.

9) Smith, J. C. and Feldman, J. L. : In vitro brainstem-spinal cord preparations for study of motor systems for mammalian respiration and locomotion. J. Neurosci. Methods. 21 : 321-333, 1987.

10) Onimaru, H. : Studies of the respiratory center using isolated brainstem-spinal cord preparations. Neurosci. Res. 21: 183-190, 1995.

11) Kudo, N. and Yamada, T. : N-methyl-D, Laspartate-induced locomotor activity in a spinal cord-hindlimb muscles preparation of the newborn rat studied in vitro. Neurosci. Lett. $75: 43-48,1987$.

12) Smith, J. C., Feldman, J. L. and Schhmidt, B. J. : Neural mechanisms generating locomotion studied in mammalian brainstem-spinal cord in vitro. FASEB J. $2:$ 2283-2288, 1988.

13) Cazalets, J. R., Sqalli-Houssaini, Y. and Clarac, F. : Activation of the central pattern generators for locomotion by serotonin and excitatory amino acids in neonatal rat. J. Physiol. 455 : 187-204, 1992.

14) Grillner, S., McClellan, A., Sigvardt, K.,Wallén, P. and Wallén, M. : Activation of NMDA-receptors elicits "fictive locomotion" in lamprey spinal cord in vitro. Acta physiol. Scand. 113 :
549-551, 1981.

15) Harris-Warrick, R. M. : Chemical modulation of central pattern generators. In : Cohen, A. H., Rossignol, S. and Grillner, S. (Eds.), Neural Control of Rhythmic Movements in Vertebrates. New York, 1988, John Wiley, 285-331.

16) Kudo, N., Ozaki, S. and Yamada, Y.: Ontogeny of rhythmic activity in the spinal cord of the rat. In : Shimamura, M., Grillner, S. and Edgerton, V. R. (Eds.), Neurobiological Basis of Human Locomotion. Tokyo, 1991, Japan Scientific Societies Press, 127-136.

17) Poon, M. : Induction of swimming in lamprey by L-DOPA and amino acids. J. Comp. Physiol. $136: 337-344,1980$.

18) Brodin, L., Grillner, S. and Rovainen, C. M. : NMDA, kainate and quisqualate receptors and the generation of fictive locomotion in the lamprey spinal cord. Brain Res. $325: 302-306$, 1985.

19) Brodin, L. and Grillner, S. : The role of putative excitatory amino acid neurotransmitters in the initiation of locomotion in the lamprey spinal cord. I. The effects of excitatory amino acid antagonists. Brain Res. 360:139-148, 1985.

20) Katakura, N., Liu, J. and Nakamura, Y. : NMDA-induced rhythmical activities of the hypoglossal motoneurons in an in vitro brainstem-spinal cord preparation from newborn rats. Neurosci. Res. Suppl. 19 : S 176, 1994.

21) Katakura, N., Liu, J. and Nakamura, Y. : NMDA-induced rhythmical activity in XII nerve of isolated CNS from newborn rat. Neuroreport. $6: 601-604,1995$.

22) Katakura, N. and Nakamura, Y. : Suckinglike activity in in vitro brainstem preparation from newborn rats. J. Dent. Res. $74: 513$, 1995.

23) Nakamura, Y. and Katakura, N. : Generation of masticatory rhythm in the brainstem. Neurosci. Res. 23:1-19, 1995.

24) Lichtman, J. W., Wilkinson, R. S. and Rich, M. M. : Multiple innervation of tonic endplates revealed by activity-dependent uptake of fluorescent probes. Nature. 314:357-359, 1985.

25) Keifer, J., Vyas, D. and Houk, J. C. : Sulforhodamine labeling of neural circuits engaged in motor pattern generation in the in vitro turtle brainstem-cerebellum. J. Neurosci. 12(8) : 3187-3199, 1992.

26) Westneat, M. W. and Hall, W. G. : Ontogeny of feeding motor patterns in infant rats; an 
electromyographic analysis of sucking and chewing. Behav. Neurosci. 106:539-554, 1992.

27) Kessler, J. P., Cherkaoui, N., Catalin, D. and Jean, A. : Swallowing responses induced by microinjection of glutamate and glutamate agonists into the nucleus tractus solitarius of ketamine-anaesthetized rats. Exp. Brain Res. $83: 151-158,1990$.

28) Carpenter, D. O. : Central nervous system mechanisms in deglutition and emesis. In : Wood, J. D. (Ed.), Handbook of Physiology ; The Gastrointestinal System. Motility and Circulation 1. Bethesda, 1989, American Physiological Society, 685-714.

29) Kriegstein, A. R., Avilla, J. G. and Blanton, M. G. : Distribution of increased synaptic activity during focal and generalized epileptiform activity revealed by presynaptic uptake of fluorescent dyes. Soc. Neurosci. Abstr. 14: 471, 1988.

30) Heuser, J. E. and Reese, T. S. : Evidence for recycling of synaptic vesicle membrane during transmitter release at the frog neuromuscular junction. J. Cell Biol. 57 : 315-344, 1973.

31) Borges, L. F., Elliot, P. J., Gill, R., Iversen, S. D. and Iversen, L. L. : Selective extraction of small and large molecules from the cerebrospinal fluid by Purkinje neurons. Science. $228: 346-348,1985$.

32) Nozaki, S., Iriki, A. and Nakamura, Y.: Trigeminal premotor neurons in the bulbar parvocellular reticular formation participating in induction of rhythmical activity of trigeminal motoneurons by repetitive stimulation of the cerebral cortex in the guinea pig. J. Neurophysiol. 69 : 595-608, 1993.

33) Kessler, J. P. and Jean, A. : Identification of the medullary swallowing regions in the rat. Exp. Brain Res. 57 : 256-263, 1985.

34) Kessler, J. P. and Jean, A. : Inhibition of the swallowing reflex by local application of serotonergic agents into the nucleus of the solitary tract. European J. Pharmacol. 118:77-85, 1985.

35) Kessler, J. P. and Jean, A. : Effect of catecholamines on the swallowing reflex after pressure injections into the lateral solitary complex of the medulla oblongata. Brain Res. 386: 69-77, 1986.

36) Tallaksen-Greene, S. J., Young, A. B., Penney, J. B. and Beitz, A. J. : Excitatory amino acid binding sites in the trigeminal principal sensory and spinal trigeminal nuclei of the rat. Neurosci. Lett. 141: 79-83, 1992.

37) Dohrn, C.S. and Beitz, A. J. : NMDA receptor mRNA expression in NOS-containing neurons in the spinal trigeminal nucleus of the rat. Neurosci. Lett. 175 (1-2) : 28-32, 1994.

38) Dohrn, C.S. and Beitz, A. J. : Differential NMDA NR 1 mRNA expression among spinal trigeminal neurons that project to different targets. Neuroreport. 5(15) : 1857-1860, 1994. 